Resenha por: Ana Amorim ${ }^{1}$

\title{
DIREITOS DOS PACIENTES E RESPONSABILIDADE MÉDICA
}

André Gonçalo Dias Pereira, Centro de Direito Biomédico, Coimbra: Coimbra Editora, 2015

${ }^{1}$ Universidade do Porto. Porto, Portugal.

Correspondência: Ana Amorim. E-mail: anasamorim@hotmail.com.

Recebido em: 17/08/2015. 
A vasta obra de André Gonçalo Dias Pereira demonstra sua clara dedicação ao estudo do Direito da Medicina, área em franca expansão e cujo célere desenvolvimento é suscetível de demandar não apenas um aprofundado estudo de todas as questões associadas ao tema, mas também uma emergente alteração normativa que melhor proteja os intervenientes na relação que se estabelece entre médico e paciente. A obra que ora analisamos divide-se em quatro partes: (I) o direito e a medicina na aurora do século XXI, (II) o Direito Civil (da medicina) como organizador do contacto da vida humana com a (Bio)medicina, (III) os direitos da pessoa doente, (IV) a responsabilidade civil médica.

Em sua mais recente investigação, o autor elege para reflexão as problemáticas essenciais associadas aos direitos do paciente, sujeito em posição de maior vulnerabilidade numa relação (desequilibrada) que é encarada como um dos elementos basilares da prática médica atual e que se estabelece quando a esfera jurídica do paciente entra em contato com a atividade médica.

A opção sistemática reflete, num primeiro momento, uma clara preocupação em contextualizar o lugar que o paciente ocupa na atividade médica atual. Na primeira parte, de natureza introdutória, o autor faz uma abordagem histórica do papel do doente, tecendo considerações acerca da mudança de paradigma que se verificou nos últimos anos na área do direito médico e que muito contribuiu para o aumento da litigiosidade no que concerne à responsabilidade médica - fator relevante para a crise da responsabilidade civil médica que hoje experenciamos. Saliente-se que a relevância atualmente atribuída à responsabilização do médico decorre dessa mudança de padrão no que tange à arte de cuidar do paciente - mudança esta que, em parte, ficou a dever-se ao progresso técnico e científico a que temos assistido nos últimos anos. E, se no passado a prática médica era pautada por certa sacralidade, hoje é ponto assente a possibilidade de responsabilização do médico, que deixa de ocupar uma posição de superioridade e impunidade face ao enfermo. Porém, embora consideremos que o progresso técnico-científico não tenha produzido alterações por demais no âmago da própria medicina, além de ter contribuído para a mudança de paradigma aludida, ele ainda pode colocar em risco a relação médico-paciente. Para tal, e nas palavras do autor quando este se reporta à medicina do presente, "o paciente é o sujeito e o centro da relação. Urge recolocar a pessoa no centro da intervenção médica e como o foco de proteção do Direito"'. Não esqueçamos que a medicina é feita para servir o homem e que, desde a época em que vigorava o paternalismo herdado de Hipócrates, o objetivo fulcral do médico é cuidar do paciente, zelando sempre por seu bem-estar físico e psíquico.

Na parte II, ocupa-se o autor do estudo de diversas questões que, embora numa primeira análise possam aparentar não possuir uma direta conexão com o

${ }^{1}$ PEREIRA, André Gonçalo Dias. Direitos dos pacientes e responsabilidade médica. Coimbra: Centro de Direito Biomédico; Coimbra Ed., 2015. v. 22, p. 158. 
cerne da investigação, relacionam-se com a tutela dos direitos de personalidade do doente plasmados nos diversos diplomas legais do ordenamento jurídico português. Ainda que concordemos com a divisão sistemática feita pelo autor com vista à abrangência das diversas temáticas que - dependendo da casuística em questão - podem contender com os direitos fundamentais do paciente, denota-se nesta parte certa dispersão em relação ao enfoque do trabalho. Somos em crer que os temas aqui abordados são suscetíveis de fundamentarem per se um estudo doutrinário aprofundado e adequado à sua relevância atual para o Direito da Medicina. Parece-nos que uma dispersão de tal natureza pode distrair e, consequentemente, afastar o leitor do cerne da investigação, levando-o por trilhos merecedores de um tratamento isolado por parte da doutrina. Contudo, o próprio autor - atento às dificuldades em restringir um tema tão abrangente como o dos "direitos dos pacientes" - reconhece a existência de tal descentralização, fundamentando sua opção sistemática na tradição dos estudos de Coimbra:

Na tradição da Faculdade de Direito de Coimbra não é, porém, desadequado - parece-nos - a elaboração de uma Dissertação de Doutoramento que faça uma prospeção horizontal de um grande tema, que veja parte da floresta e que não se concentre apenas numa árvore ${ }^{2}$.

A parte III é dedicada à análise da relação médico-doente com base no estudo dos direitos e deveres que caracterizam essa relação, bem como no estudo dos pilares fundamentais da prática médica atual. $\mathrm{O}$ autor debruça-se sobre as especificidades dos direitos e, consequentemente, dos deveres atribuídos quer ao paciente quer ao clínico - o direito à informação, ao consentimento informado $\mathrm{e}$ às declarações antecipadas de vontade, o direito à documentação e ao acesso à informação pessoal de saúde. É feita ainda uma abordagem do direito à reserva da intimidade da vida privada através da consideração da doutrina do sigilo médico. A mudança de comportamento dos médicos em relação aos direitos dos pacientes encontra-se plasmada nesta parte, na qual o autor demonstra a importância atribuída hoje em dia à autonomia, vontade e autodeterminação do paciente enquanto sujeito apto a decidir de forma livre e esclarecida o que pode ou não ser feito ao seu corpo de acordo com as suas crenças, experiências e opções de vida. Se na época do paternalismo clínico herdado de Hipócrates a possibilidade de decidir era colocada nas mãos do médico, o surgimento da teoria dos direitos fundamentais, associada ao reconhecimento da autonomia do paciente, contribuiu bastante para a alteração das características da relação médico-paciente, que possui hoje uma importância crescente. Atendendo à natural abrangência do tema dos direitos dos pacientes, opta o autor apenas pelo tratamento daqueles direitos que se afiguram mais relevantes face ao Direito da Medicina atual. Estabelece como um dos objetivos de sua obra

${ }^{2}$ PEREIRA, André Gonçalo Dias. op. cit., p. 887. 
o tratamento adequado do "direito a cuidados de saúde de qualidade [...], direito à informação e ao consentimento, direito à confidencialidade da informação de saúde e direito à documentação clínica (e ao seu acesso)"3. Refere ainda que, no ordenamento jurídico português, existe legislação que regula os direitos e deveres dos cidadãos. Contudo, face às lacunas legais existentes, recomenda o autor a redação de uma lei que se debruce especificamente sobre a doutrina do consentimento informado ${ }^{4}$, devendo tal diploma legal abranger o dever de informação, a capacidade para consentir, a forma como a informação deve ser prestada e, posteriormente, como a autorização para a realização do ato médico deve ser recolhida e, finalmente, o direito de acesso à informação de saúde.

A obra encerra com um aprofundado estudo acerca da possibilidade de o médico ser civilmente responsabilizado pelos danos decorrentes de sua atuação profissional - responsabilidade que, dependendo das características do caso concreto, pode igualmente ser atribuída à instituição de saúde onde decorreu o ato médico que produziu danos na esfera jurídica do paciente. E, encarando sempre o doente como o cerne da prática médica, são várias as propostas apresentadas para que o Direito da Medicina seja cada vez mais direcionado para a segurança do paciente. Alerta ainda o autor para a carência de normas legais específicas que regulem a responsabilidade médica à qual, na maioria dos casos, é aplicável o regime geral da responsabilidade civil.

No âmbito dessa investigação, o autor deteta uma necessidade emergente de análise doutrinal e adequação normativa à realidade atual do Direito da Medicina, de forma a travar a contínua degradação da relação médico-paciente e a diminuir a litigância que, naturalmente, contribui para a existência de um clima de conflito entre os intervenientes nessa relação jurídica. Cumpre perceber se o enquadramento jurídico atual da atividade médica permite as mudanças propostas, numa clara aproximação entre o ordenamento jurídico português e o direito comparado.

Da análise da obra, resulta a exaltação de uma necessidade urgente e crescente de proteção dos direitos dos pacientes face aos riscos que a medicina pode comportar. Afigura-se, ainda, essencial a existência de um Direito da Medicina que garanta o desenvolvimento das ciências médicas em conformidade com o respeito aos direitos humanos. Somos em crer que, devido ao estudo global encetado pelo autor e complementado pela constante análise comparativa entre a legislação e jurisprudência do direito comparado e o atual estado da medicina no panorama jurídico nacional, essa obra apresente indiscutível importância para uma melhor compreensão dos direitos do paciente no presente, abrindo já caminho às alterações emergentes de um ramo do direito tão atual e relevante como é o caso do Direito da Medicina.

${ }^{3}$ PEREIRA, André Gonçalo Dias. op. cit., p. 374.

${ }^{4}$ Refira-se que a problemática do consentimento informado tinha sido já amplamente tratada pelo autor no âmbito de sua dissertação de mestrado. PEREIRA, André Gonçalo Dias. O consentimento informado na relação médico-paciente: estudo de direito civil. Coimbra: Centro de Direito Biomédico; Coimbra Ed., 2004. v. 9. 


\section{Referências}

PEREIRA, André Gonçalo Dias. O consentimento informado na relação médico-paciente: estudo de direito civil. Coimbra: Centro de Direito Biomédico; Coimbra Ed., 2004. v. 9.

PEREIRA, André Gonçalo Dias. Direitos dos pacientes e responsabilidade médica. Coimbra: Centro de Direito Biomédico; Coimbra Ed., 2015. v. 22.

Ana Amorim - Doutoranda do Curso de Doutoramento Interdisciplinar em Ciências Forenses Medicina Legal pela Faculdade de Medicina da Universidade do Porto. Jurista. Porto, Portugal. E-mail: anasamorim@hotmail.com. 